\title{
A 200 year sub-annual record of sulfate in West Antarctica, from 16 ice cores
}

\author{
Daniel DIXON, Paul A. MAYEWSKI, Susan KASPARI, Sharon SNEED, Mike HANDLEY \\ Climate Change Institute, University of Maine, 303 Bryand Global Sciences Center, Orono, ME 04469, USA \\ E-mail: daniel.dixon@maine.edu
}

\begin{abstract}
Sixteen high-resolution ice-core records from West Antarctica and South Pole are used to examine the spatial and temporal distribution of sulfate for the last 200 years. The preservation of seasonal layers throughout the length of each record results in a dating accuracy of better than $\mathbf{1}$ year based on known global-scale volcanic events. A dual transport source for West Antarctic sea-salt (ss) $\mathrm{SO}_{4}{ }^{2-}$ and excess (xs) $\mathrm{SO}_{4}{ }^{2-}$ is observed: lower-tropospheric for areas below $1000 \mathrm{~m}$ elevation and mid-/upper-tropospheric/stratospheric for areas located above $1000 \mathrm{~m}$. Our $\mathrm{xsSO}_{4}{ }^{2-}$ records with volcanic peaks removed do not display any evidence of an anthropogenic impact on West Antarctic $\mathrm{SO}_{4}{ }^{2-}$ concentrations but do reveal that a major climate transition takes place over West Antarctica at $\sim 1940$. Global-scale volcanic eruptions appear as significant peaks in the robust-spline residual $\mathrm{xsSO}_{4}{ }^{2-}$ records from sites located above $1000 \mathrm{~m}$ elevation but do not appear in the residual records from sites located below $1000 \mathrm{~m}$.
\end{abstract}

\section{INTRODUCTION}

Antarctica's role in the global climate system is both pivotal and complex. West Antarctica in particular is the most dynamic area of the continent both atmospherically and glaciologically (Cullather and others, 1996; Bindschadler, 1998). It is impacted by several major atmospheric weather systems, the Amundsen Sea low and, to a lesser degree, the Weddell Sea low and the Davis Sea low. These large atmospheric low-pressure systems are the primary transport mechanisms for moisture and aerosols to the West Antarctic ice sheet.

Instrumental climate records are relatively sparse over the Southern Hemisphere and extend back $<100$ years. Over Antarctica such records extend back only a few decades. Glaciochemical proxy data can extend the paleoclimate record back hundreds to thousands of years and also provide a unique resource for examining changes in the sources, pathways and distribution of chemical species in the atmosphere through time (Mayewski and others, 1993). This paper focuses on the sulfate $\left(\mathrm{SO}_{4}{ }^{2-}\right)$ time series available from a series of 16 ice cores collected over West Antarctica.

Sulfate aerosols play a significant role in the heat budget of the global atmosphere, mainly through the scattering of incoming solar radiation and through indirect effects involving clouds (Charlson and others, 1990). In addition to anthropogenic emissions, sulfur is released into the atmosphere from a variety of natural sources including sea salt, continental dust, volcanic eruptions, the terrestrial biosphere and the marine biosphere.

Major volcanic events such as the eruption of Pinatubo, Philippines, in 1991 can inject large volumes of sulfur gases $\left(\mathrm{H}_{2} \mathrm{~S}, \mathrm{SO}_{2}\right)$, ash, dust and crustal material directly into the stratosphere. Most large volcanic eruptions (such as Krakatau, Indonesia, in 1883 and Agung, Indonesia, in 1963) significantly increase stratospheric $\mathrm{SO}_{4}{ }^{2-}$ concentrations for at least 1-2 years after the event. Occasionally, an exceptionally large eruption, such as Tambora, Indonesia, will increase atmospheric $\mathrm{SO}_{4}{ }^{2-}$ concentrations for 3-4 years (Self and others, 1981). Large volcanic eruptions significantly affect stratospheric chemistry, inducing a higher catalytic destruction rate of ozone, resulting in enhanced levels of ultraviolet range B (UV-B) radiation at the Earth's surface (Berresheim and others, 1995).

Antarctica is an ideal place to study natural atmospheric $\mathrm{SO}_{4}{ }^{2-}$ variability due to its isolated location, the fact that Antarctic precipitation is an excellent repository for the deposition of soluble and insoluble chemical species, and its remoteness from major anthropogenic $\mathrm{SO}_{4}{ }^{2-}$ sources that can confound the investigation of natural variability over more populated regions (Shaw, 1982; Legrand and Mayewski, 1997). The primary types of $\mathrm{SO}_{4}{ }^{2-}$ in Antarctic aerosols are sea-salt (ss) $\mathrm{SO}_{4}{ }^{2-}$ and excess (xs) $\mathrm{SO}_{4}{ }^{2-}$, the latter composed predominantly of marine biogenic emissions, volcanic emissions (Delmas, 1982; Legrand, 1997) and an as yet either non-existent or undetermined contribution from anthropogenic activity. Marine biogenic emissions dominate the overall sulfur budget in the Southern Hemisphere (Bates and others, 1992; Legrand and Mayewski, 1997).

In this study, 16 sub-annually resolved, continuously sampled, multivariate ice-core records (15 from West Antarctica and 1 from South Pole; Fig. 1) are used to investigate ice-core $\mathrm{SO}_{4}{ }^{2-}$ concentrations over West Antarctica. The 16 ice cores capture the sub-annual variability in Antarctic $\mathrm{SO}_{4}{ }^{2-}$ loading over the period 1487-2002, with a 200 year overlap (1799-1992) for six of the cores, a 101 year overlap (1891-1992) for 11 of the cores and a 50 year overlap (1952-92) for all cores except 01-6 (Table 1).

Each ice-core $\mathrm{SO}_{4}{ }^{2-}$ time series is separated into its primary constituents $\mathrm{SsSO}_{4}{ }^{2-}$ and $\mathrm{xSSO}_{4}{ }^{2-}$, from which the spatial and temporal variation of these fractions is investigated for the period of the last 200 years. The methods used for separating ss from xs are discussed later. Volcanic peaks are extracted from the $\mathrm{xsSO}_{4}{ }^{2-}$ time series by calculating the residuals from a robust-spline smoothing of the raw $\mathrm{xSSO}_{4}{ }^{2-}$ data following the technique used by Zielinski and others (1994). Several well-documented volcanic events are detected in each $\mathrm{xsSO}_{4}{ }^{2-}$ series and these are used to reinforce the identification of annual-layer dating by providing absolute depth-age horizons. 


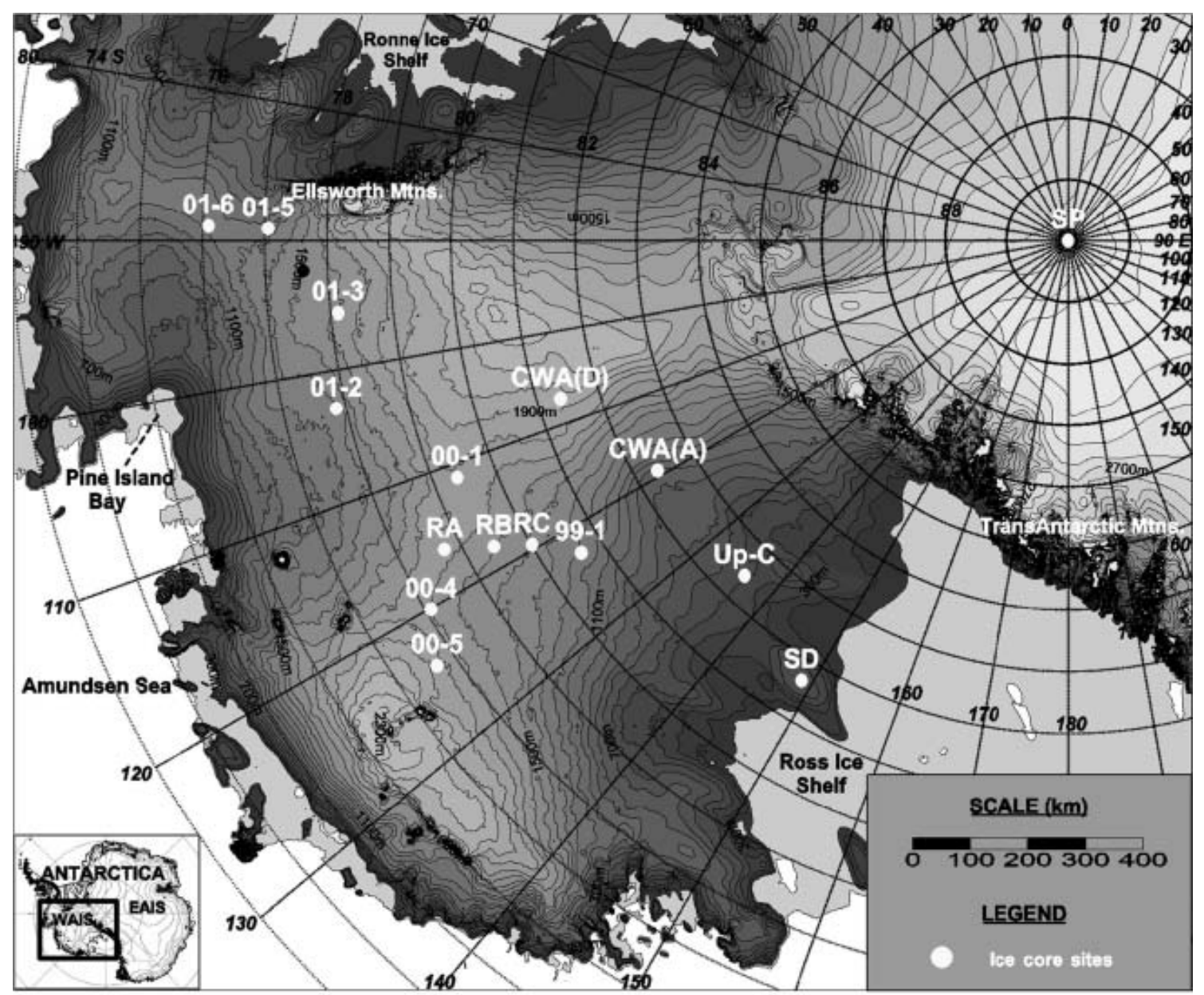

Fig. 1. Location map of sites for all ice cores used in this study. RA, RB and RC represent core sites RIDS-A, RIDS-B and RIDS-C, respectively. Map created using the RADARSAT-1 Antarctic Mapping Project (RAMP) digital elevation model (Liu and others, 2001).

The $\mathrm{xsSO}_{4}{ }^{2-}$ remaining after removal of the volcanic peaks is the robust-spline smoothed $\mathrm{xsSO}_{4}{ }^{2-}$. This remaining $\mathrm{xSSO}_{4}{ }^{2-}\left(\mathrm{rxSSO}_{4}{ }^{2-}\right)$ is assumed to be a mixture of total marine biogenic $\mathrm{SO}_{4}{ }^{2-}$ and stratospheric background $\mathrm{SO}_{4}{ }^{2-}$. The stratospheric background $\mathrm{SO}_{4}{ }^{2-}$ is potentially composed of non-explosive volcanic $\mathrm{SO}_{4}{ }^{2-}$, an admixture of sources that reside in polar stratospheric clouds, and continental $\mathrm{SO}_{4}{ }^{2-}$ sources such as anthropogenic emissions and dust.

\section{THE ANTARCTIC ATMOSPHERE AND $\mathrm{SO}_{4}{ }^{2-}$ AEROSOLS}

Throughout the year, Antarctic coastal and low-elevation areas are strongly influenced by lower-tropospheric air masses compared to higher-elevation interior areas. The influence of mid-/upper-tropospheric and stratospheric air masses on coastal sites is minor (Minikin and others, 1998; Legrand and Wagenbach, 1999). The sea-salt fraction of the total $\mathrm{SO}_{4}{ }^{2-}$ budget is large at coastal and low-elevation sites, contributing over $\sim 25 \%$ to sites such as Siple Dome (Table 1). Several studies have shown that $\mathrm{xsSO}_{4}{ }^{2-}$ concentrations and deposition timing are similar from site to site around the Antarctic coastline (Prospero and others, 1991; Legrand and Pasteur, 1998; Minikin and others, 1998; Legrand and Wagenbach, 1999). This similarity implies that $\mathrm{xsSO}_{4}{ }^{2-}$ concentrations at coastal Antarctic sites are controlled by large-scale processes related to both the distribution of sulfur sources in the Southern Ocean and the atmospheric mixing and transport patterns (Prospero and others, 1991). Coastal $\mathrm{xsSO}_{4}{ }^{2-}$ concentrations are influenced throughout the year by long-range transport of marine biogenic emissions from mid-latitude sources located at 50$60^{\circ} \mathrm{S}$. During the summer months these same coastal sites are inundated by $\mathrm{xsSO}_{4}{ }^{2-}$ from marine biogenic sources located south of $60^{\circ} \mathrm{S}$ (Minikin and others, 1998). Concentrations of $\mathrm{xsSO}_{4}{ }^{2-}$ at coastal sites exhibit a well-defined peak from November to January. This summer $\mathrm{xsSO}_{4}{ }^{2-}$ peak corresponds to the break-up of the Antarctic sea ice south of $60^{\circ} \mathrm{S}$ and a subsequent enrichment of chlorophyll concentrations (Minikin and others, 1998). The marine biogenic $\mathrm{xSSO}_{4}{ }^{2-}$ component accounts for roughly two-thirds of the winter and $>90 \%$ of the summer coastal $\mathrm{xsSO}_{4}{ }^{2-}$ concentrations (Minikin and others, 1998). The remaining percentage of winter and summer coastal $\mathrm{xsSO}_{4}{ }^{2-}$ comes from sources such as long-range transport from continental areas and sedimentation from the stratospheric reservoir.

High-elevation areas such as inland West Antarctica, South Pole and the Polar Plateau also receive $\mathrm{SO}_{4}{ }^{2-}$ from a variety of sources. The $\mathrm{ssSO}_{4}{ }^{2-}$ fraction peaks during the winter/spring transition months when intense cyclonic activity and intrusions of lower-tropospheric marine air masses are common (Legrand and others, 1992; Whitlow and others, 1992; Hogan, 1997). The oceans surrounding Antarctica are ice-covered during the winter/spring 
Table 1. Information for each ice core used in this study. Elev. = elevation; Mean acc. = mean annual accumulation; conc. = concentration; Sampling res. = sampling resolution; and Samples per year $=$ mean number of samples per year calculated from entire high-resolution section of each core

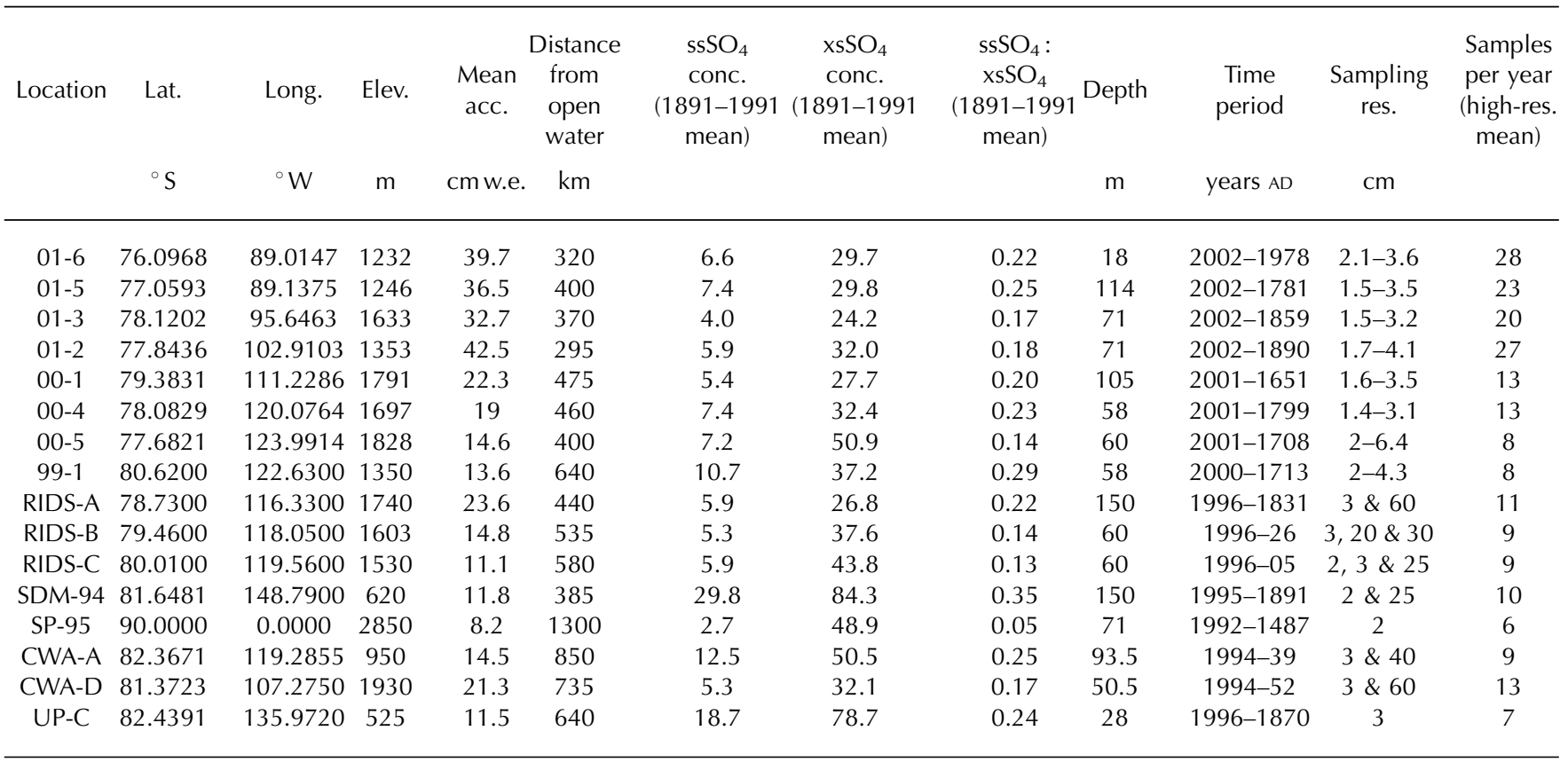

transition. Therefore, a low-/mid-latitude source is proposed for the $\mathrm{ssSO}_{4}{ }^{2-}$ (Prospero and others, 1991). By the time lower-tropospheric parcels of air reach the Polar Plateau they are severely depleted of heat, moisture and aerosols due to the long distances traveled (Hogan and others, 1982; Proposito and others, 2002). As a result, $\mathrm{ssSO}_{4}{ }^{2-}$ accounts for $<5 \%$ of the total $\mathrm{SO}_{4}{ }^{2-}$ budget on the Polar Plateau during the winter/spring and $<1 \%$ during the summer (Harder and others, 2000; Isaksson and others, 2001).

Mid-/upper-tropospheric air masses carry $\mathrm{xSSO}_{4}{ }^{2-}$ aerosols emitted primarily from low-/mid-latitude marine biogenic productivity sources (Shaw, 1982; Legrand and others, 1992; Minikin and others, 1998) as well as episodic $\mathrm{xsSO}_{4}{ }^{2-}$ input from volcanic eruptions (Legrand and Wagenbach, 1999). The $\mathrm{SO}_{4}{ }^{2-}$ contained in these mid-/upper-tropospheric air masses dominates the summer $\mathrm{SO}_{4}{ }^{2-}$ budget of high-elevation Antarctic areas, such as inland West Antarctica, South Pole and the interior portions of the Polar Plateau (Delmas and Boutron, 1978; Delmas, 1982; Kreutz and Mayewski, 1999; Harder and others, 2000; Isaksson and others, 2001).

High-elevation Antarctic areas are also impacted by the stratospheric $\mathrm{SO}_{4}{ }^{2-}$ layer. The stratospheric contribution of $\mathrm{SO}_{4}{ }^{2-}$ is generally assumed to be weak (Legrand, 1997; Bergin and others, 1998) except after global-scale volcanic eruptions (Legrand and Delmas, 1987; Dibb and Whitlow, 1996). The $\mathrm{SO}_{4}{ }^{2-}$ aerosols in the stratosphere sink and mix downward into the troposphere. The slow sedimentation of $\mathrm{SO}_{4}{ }^{2-}$ from the stratosphere is periodically enhanced by disruptions to the tropopause that often occur during the spring break-up of the polar vortex (Saxena and others, 1995).

\section{METHODOLOGY}

Of the sixteen cores used in this study, eight have been previously reported. The Siple Dome core (SDM94) and the three Ross ice drainage system cores (RIDS-A, -B and -C) were collected by a University of New Hampshire team in 1994 and 1995 respectively (Mayewski and others, 1995; Kreutz and others, 1996, 1999, 2000). The South Pole core (SP95) was collected by the Polar Ice Coring Office (PICO) in the designated clean-air sector, $\sim 1.5 \mathrm{~km}$ upwind from South Pole Station in 1995 (Battle and others, 1996; Meyerson and others, 2002). The central West Antarctic cores (CWA-A and -D) were collected during the 1994/95 field season by a University of Wisconsin team, and the results are reported by Reusch and others, (1999). The Up-C ice core was collected during the 1995/96 field season by PICO for Pennsylvania State University.

The eight new cores used in this study were drilled during the US International Trans-Antarctic Scientific Expedition (ITASE) West Antarctic traverses of 1999-2001 and analyzed at sub-annual, continuous resolution (Table 1). The samples were melted using the University of Maine continuous melter system, yielding, for this study, an average resolution of $\sim 50$ samples per meter. This high sampling resolution captures the clear seasonal signal that is present in each ion time series (Fig. 2). All samples were examined for their soluble major-ion content $\left(\mathrm{Na}^{+}, \mathrm{K}^{+}, \mathrm{Mg}^{2+}, \mathrm{Ca}^{2+}, \mathrm{Cl}^{-}, \mathrm{NO}_{3}{ }^{-}\right.$, $\mathrm{SO}_{4}{ }^{2-}$ ). Each was analyzed using a Dionex ${ }^{\circledR}$ DX-500 ion chromatograph coupled to a Gilson ${ }^{\circledR}$ autosampler. To determine anion $\left(\mathrm{Cl}^{-}, \mathrm{SO}_{4}{ }^{2-}\right.$ and $\left.\mathrm{NO}_{3}{ }^{-}\right)$concentrations, the chromatograph was set up with an AS-11 column with $6 \mathrm{mM}$ $\mathrm{NaOH}$ eluent. For cation $\left(\mathrm{Na}^{+}, \mathrm{Ca}^{2+}, \mathrm{Mg}^{2+}\right.$ and $\left.\mathrm{K}^{+}\right)$ concentrations, a CS-12a column with $25 \mathrm{mM}$ MSA eluent was used. All ion concentrations are determined with an accuracy of better than $0.1 \mathrm{ppb}$.

The 1999-2001 cores are annually dated by matching seasonal peaks from each of the ion time series (Fig. 2). A 'core-chemistry' year is defined by a winter-spring peak in $\mathrm{Na}^{+}, \mathrm{K}^{+}, \mathrm{Mg}^{2+}, \mathrm{Ca}^{2+}$ and $\mathrm{Cl}^{-}$combined with spring-summer peaks in both $\mathrm{NO}_{3}{ }^{-}$and $\mathrm{xSSO}_{4}{ }^{2-}$, in accord with the 


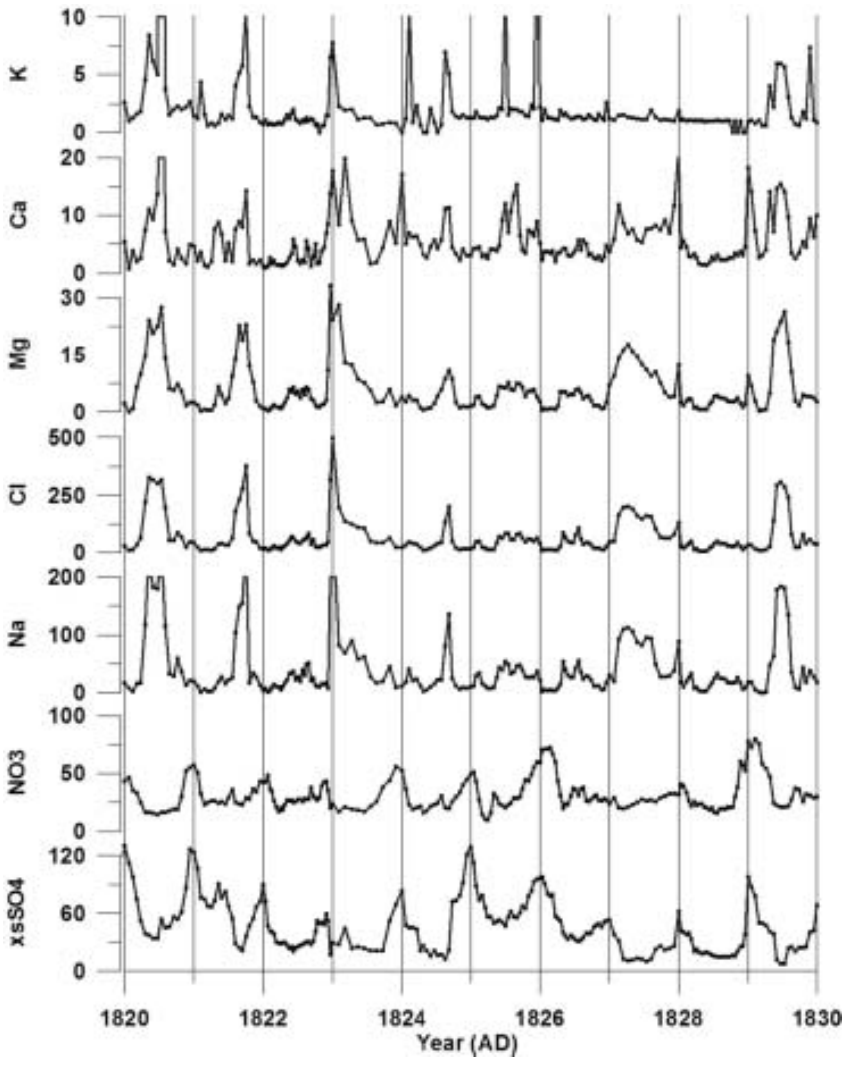

Fig. 2. Raw ion data from core 01-5 plotted vs time. Ion concentrations are in parts per billion. These data are from 94-99 m depth (AD 1820-30) in the core. Vertical lines represent 1 year increments.

seasonal timing identified by previous research (e.g. Whitlow and others, 1992; Wagenbach, 1996; Legrand and Mayewski, 1997; Kreutz and Mayewski, 1999). Counting the seasonal layers down to absolute depth-age horizons (e.g. the Tambora 1815 volcanic event) demonstrates that each year is preserved in the sub-annual records of each core (Fig. 3) and that lower-resolution records cannot be used to accurately date volcanic events. For this reason, only the high-resolution portion of each ice-core record is used in this study. Based on several well-documented global-scale volcanic depth-age horizons, a dating accuracy of better than 1 year between known volcanic events is achieved for each $\mathrm{SO}_{4}{ }^{2-}$ record. The $\mathrm{SsSO}_{4}{ }^{2-}$ fraction is calculated by applying a standard sea-water ratio of $30.61\left(\mathrm{Na}^{+}\right), 1.1\left(\mathrm{~K}^{+}\right)$, $3.69\left(\mathrm{Mg}^{2+}\right), 1.16\left(\mathrm{Ca}^{2+}\right), 55.04\left(\mathrm{Cl}^{-}\right)$and $7.68\left(\mathrm{SO}_{4}{ }^{2-}\right)$ to the ion concentrations in each sample (Holland, 1978). The concentration values are reduced incrementally according to this ratio until a value of zero is reached in one of the six ion concentrations. The ion which reaches zero concentration first is considered to be the conservative ion for that sample, and the concentration values for the other five ions are recorded. These become the excess (xs) concentrations for that sample. This technique, from O'Brien and others (1995), resulted in $\mathrm{Na}^{+}$being the conservative ion for $>90 \%$ of the samples in each core in this study. Recent studies have noted the effect of frost flowers on the ss fraction of ice-core chemistry. Frost flowers are depleted in $\mathrm{SO}_{4}{ }^{2-}$ relative to $\mathrm{Na}^{+}$ and this produces an $\mathrm{ssSO}_{4}{ }^{2-}$ value which is slightly higher than it should be for sites near the coast (Rankin and others, 2002). At this time, the magnitude of the fractionation effect

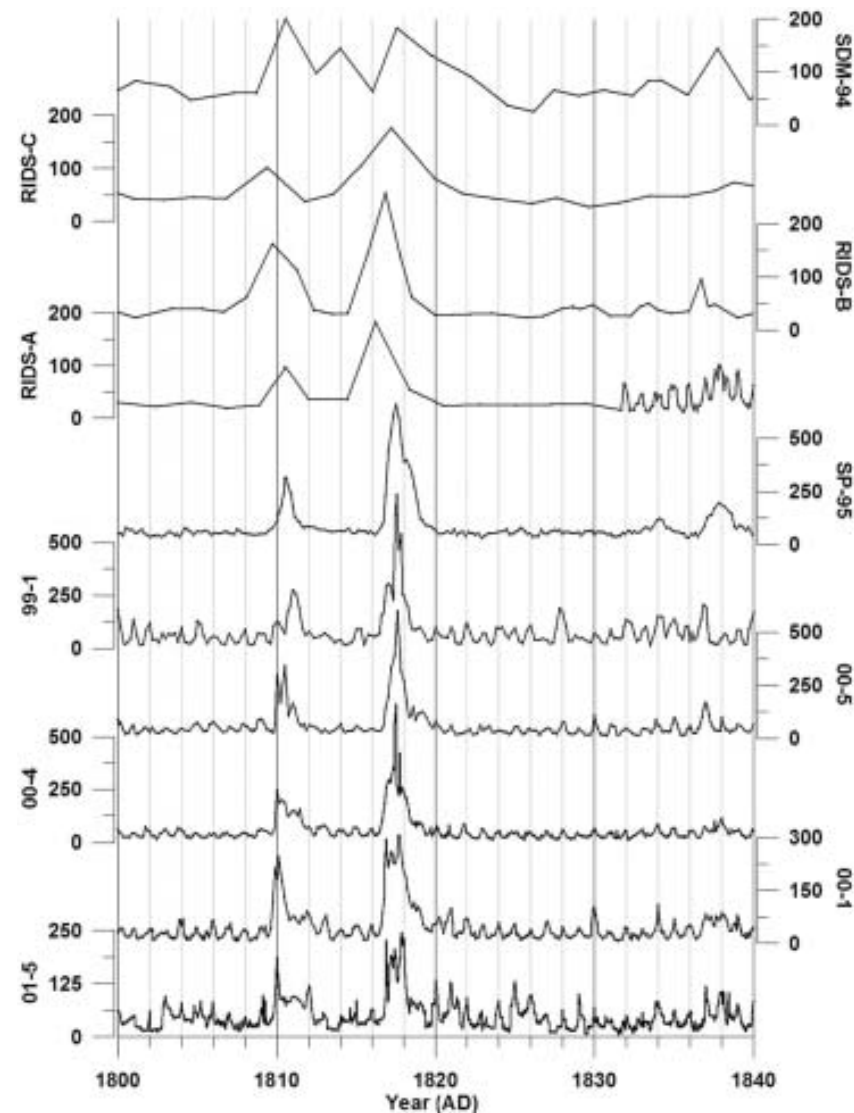

Fig. 3. Sub-annual and biannual raw excess sulfate ion concentration data for the years 1800-40 for ice cores 01-5, 00-1, 00-4, 00-5, 99-1, SP-95, RIDS-A, RIDS-B, RIDS-C and SDM-94. All concentrations are in parts per billion. Vertical lines represent 2 year increments.

is not constrained sufficiently for corrections to be made to our suite of cores.

In order to examine the spatial pattern of $\mathrm{ss}$ and $\mathrm{xsSO}_{4}{ }^{2-}$, mean concentrations from 1891 to 1991 (apart from core 01-6 which only has a 23 year record) are plotted vs site elevation, straight-line distance from the nearest open water, and mean annual accumulation rate from 1891 to 1991 (Fig. 4). The reason for averaging over this time period is that any variability at lesser time-scales will be averaged out. Similar plots were constructed using ss and $\mathrm{xsSO}_{4}{ }^{2-}$ concentrations averaged from 1891 to 1940 and 1940 to 1991 to see if mean values from these different time periods affected the results. The values, although slightly different, retained the same trends with respect to elevation, straightline distance from the nearest open water and mean annual accumulation rate. The temporal pattern of $\mathrm{SsSO}_{4}{ }^{2-}$ is examined by plotting the mean annual concentrations vs time for each core (Fig. 5). A 5 year running average is superimposed over these annual data to highlight any longterm trends. Empirical orthogonal function (EOF) analysis is used on the annual $\mathrm{ssSO}_{4}{ }^{2-}$ and $\mathrm{xsSO}_{4}{ }^{2-}$ concentrations for the years 1891-1991 and 1939-91 to see if any site-to-site associations exist in the ice-core records. These two time periods are used for the EOF calculations because the former represents the longest period of overlap between 10 of the ice-core records and the latter represents the longest period of overlap between 13 of the records (the record from 99-1 was not used in the EOF analysis because of data gaps). 
a

b
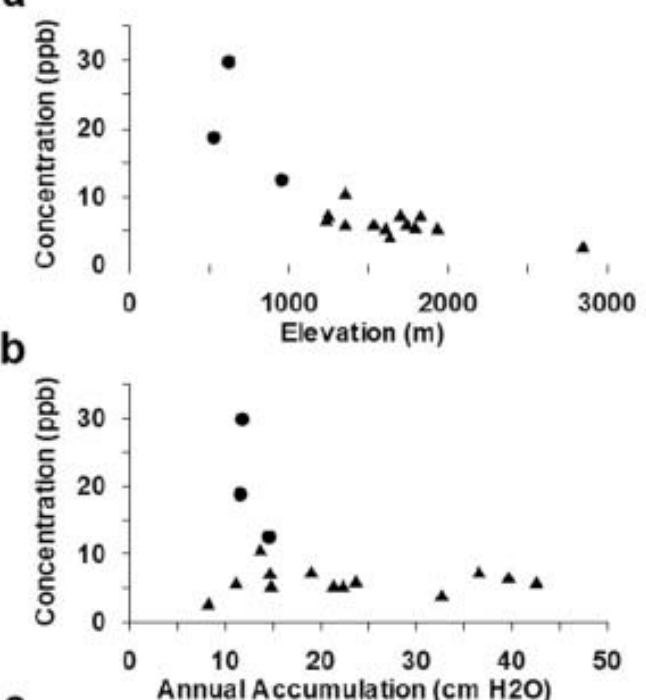

c

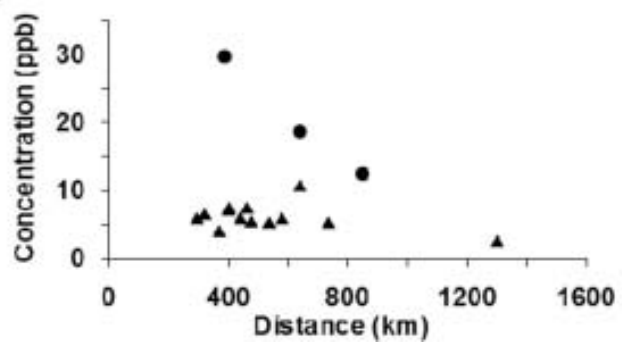

d

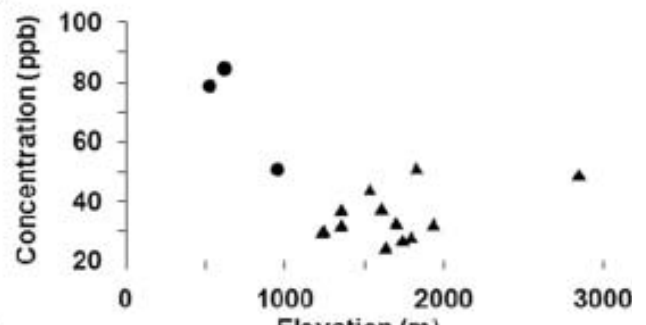

e
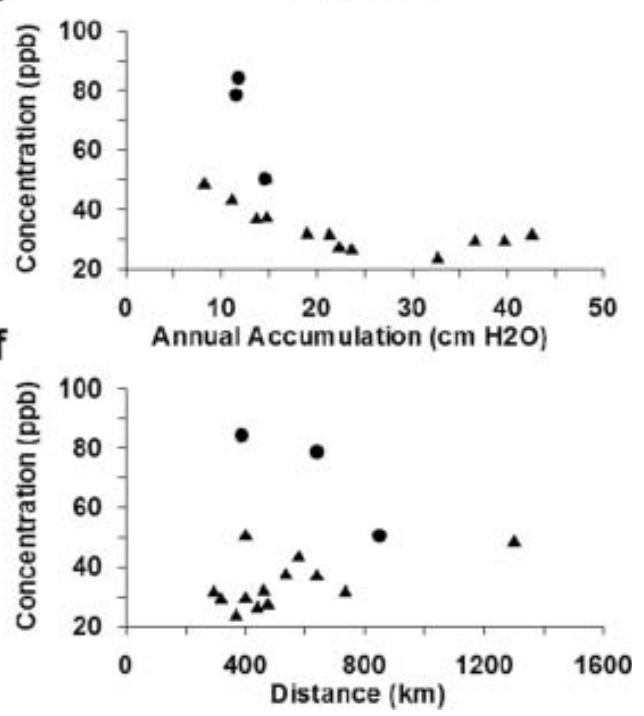

Fig. 4. Mean annual accumulations, $\mathrm{ssSO}_{4}{ }^{2-}$ and $\mathrm{xsSO}_{4}{ }^{2-}$ concentrations for the years $1891-1991$. (a) $\mathrm{ssSO}_{4}{ }^{2-}$ vs elevation; (b) $\mathrm{ssSO}_{4}{ }^{2-}$ vs mean annual accumulation; (c) $\mathrm{sSSO}_{4}{ }^{2-}$ vs straight-line distance from nearest open water; (d) $\mathrm{xsSO}_{4}{ }^{2-}$ vs elevation; (e) $\mathrm{xsSO}_{4}{ }^{2-}$ vs mean annual accumulation; and (f) $\mathrm{xSSO}_{4}{ }^{2-}$ vs straight-line distance from nearest open water. Distances to open water are ignoring sea ice. All concentrations in parts per billion.
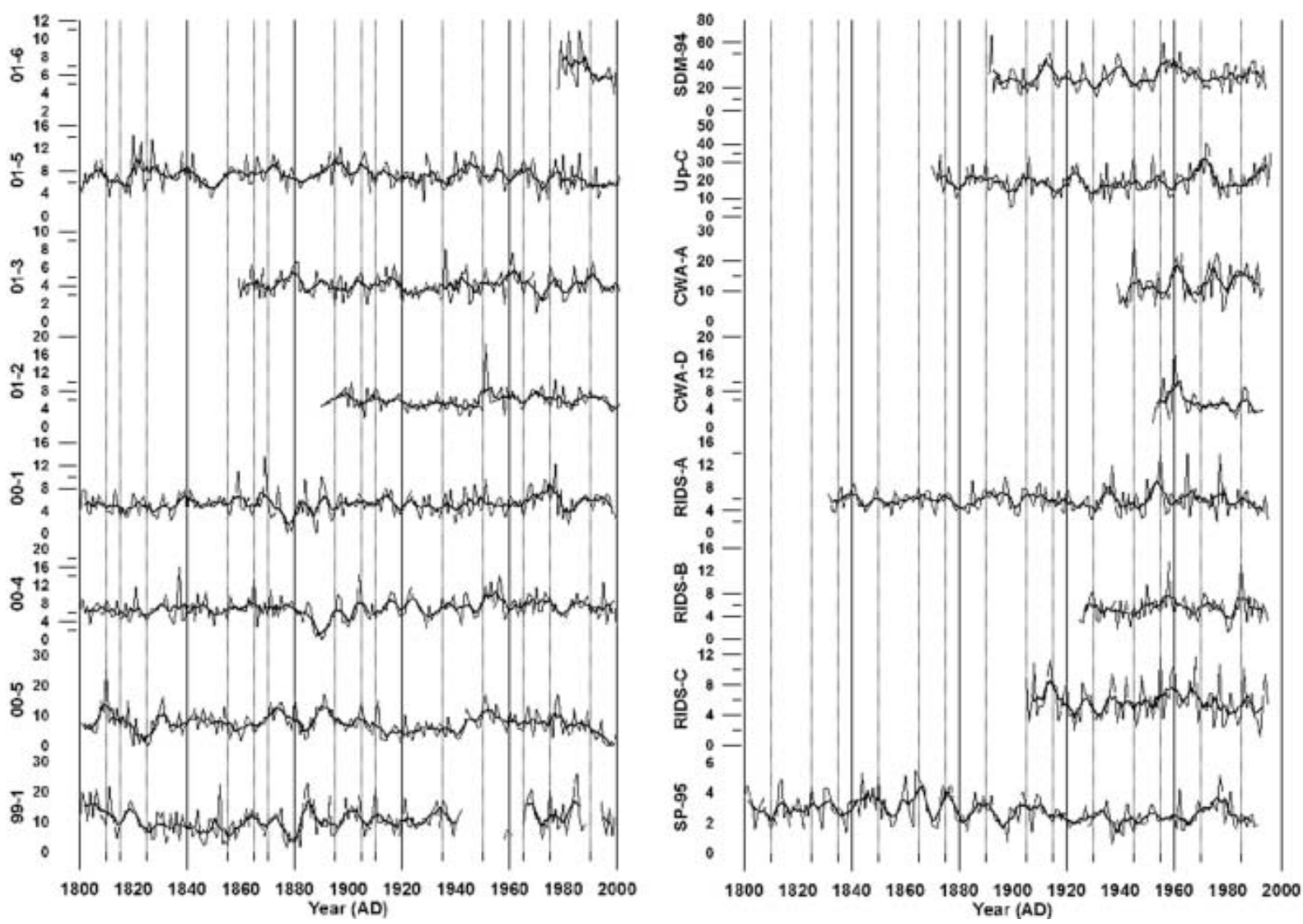

Fig. 5. Annual sea-salt sulfate concentrations in parts per billion for the years 1800-2002 for each ice core used in this study. Lighter lines represent annual concentration values, and thick darker lines represent a 5 year running average. Vertical lines represent 5 year increments. 

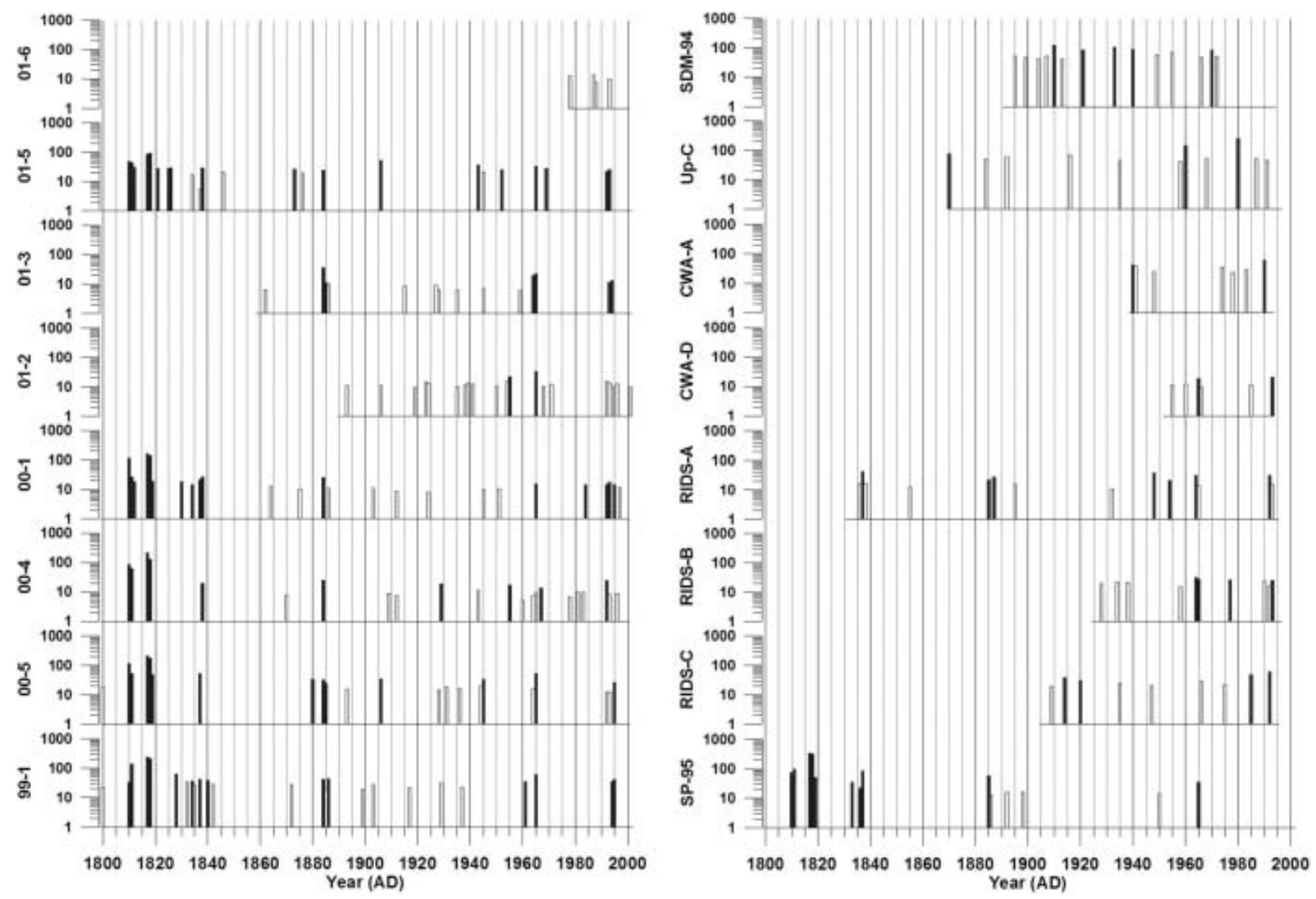

Fig. 6. Positive residuals from robust-spline smoothed annual excess sulfate concentrations for each ice core for the years 1800-2002. Peaks that are mean $+1 \sigma$ above the mean are shown in white, and peaks that are mean $+2 \sigma$ above the mean are shown in black. All concentrations are in parts per billion. Vertical lines represent 5 year increments.

Volcanic peaks are first identified from the $\mathrm{xsSO}_{4}{ }^{2-}$ data using a robust spline. A robust spline has the advantage over most smoothing functions that it is not affected by large outliers (e.g. volcanic peaks). The robust-spline tool outputs two separate time series which, when combined, make up the original series. One of these time series is the robustspline smoothed series and the other is the robust-spline residuals (peaks). The amount of smoothing applied to each $\mathrm{xsSO}_{4}{ }^{2-}$ series is $80-90 \%$, as this value provides the best approximation of the mean non-volcanic background concentrations beneath large volcanic spikes compared to adjacent years without volcanic $\mathrm{SO}_{4}{ }^{2-}$.

The first step of the robust-spline technique is to average the raw $\mathrm{xsSO}_{4}{ }^{2-}$ data to annual resolution. The annual average calculation incorporates the raw background $\mathrm{xSSO}_{4}{ }^{2-}$ concentrations into the annual values. Thus, a large volcanic event that manifests as a significant rise in background $\mathrm{xsSO}_{4}{ }^{2-}$ concentrations will be recognized by the robust spline. The robust-spline function is applied to the annually averaged $\mathrm{xSSO}_{4}{ }^{2-}$ time series and the robust-spline smoothed series, and associated $\mathrm{xsSO}_{4}{ }^{2-}$ residuals are extracted. The mean residual $\mathrm{xSSO}_{4}{ }^{2-}$ concentration is calculated from the positive post-1825 $\mathrm{xsSO}_{4}{ }^{2-}$ residual values (this prevents the large Tambora volcanic $\mathrm{xsSO}_{4}{ }^{2-}$ signal from causing an anomalously high mean residual $\mathrm{xsSO}_{4}{ }^{2-}$ value). The mean $+1 \sigma$ and mean $+2 \sigma$ residual $\mathrm{xSSO}_{4}{ }^{2-}$ values are used to isolate the larger peaks from the $\mathrm{xsSO}_{4}{ }^{2-}$ residuals. Each residual $\mathrm{xsSO}_{4}{ }^{2-}$ peak greater than the mean $+2 \sigma$ value represents a strong volcanic signal, and each residual $\mathrm{xsSO}_{4}{ }^{2-}$ peak greater than the mean $+1 \sigma$ value represents a probable volcanic signal (hereafter referred to as $1 \sigma$ and $2 \sigma$ peaks). The $1 \sigma$ and $2 \sigma$ peaks are plotted on the same time axis for each core (Fig. 6).

As it is not currently possible to unambiguously separate the total marine biogenic and background stratospheric rxsSO $_{4}{ }^{2-}$ components, the rxsSO ${ }_{4}{ }^{2-}$ time series for each core is used to examine the long-term trends in these two components over the last 200 years (Fig. 7). EOF analysis is used to determine if any associations exist between the rxsSO$_{4}{ }^{2-}$ records from 1891 to 1991 and from 1939 to 1991.

\section{RESULTS AND DISCUSSION}

\section{Ion concentrations and accumulation rate}

Previous research reveals no significant correlations between snow ion concentration and accumulation rate (e.g. Mulvaney and Wolff, 1994; Kreutz and Mayewski, 1999; Kreutz and others, 2000). This suggests that any dilution effects which do exist are offset by additional inputs such as dry and fog deposition (Bergin and others, 1995; Kreutz and others, 2000). Varying wet-deposition scavenging ratios can further confuse these effects. EOF analyses of the mean annual ion concentrations and mean annual accumulations for each US ITASE core resulted in weak correlations for most cores. The mean annual values of accumulation were used because this was the best resolution achievable for accumulation rate. The correlations 

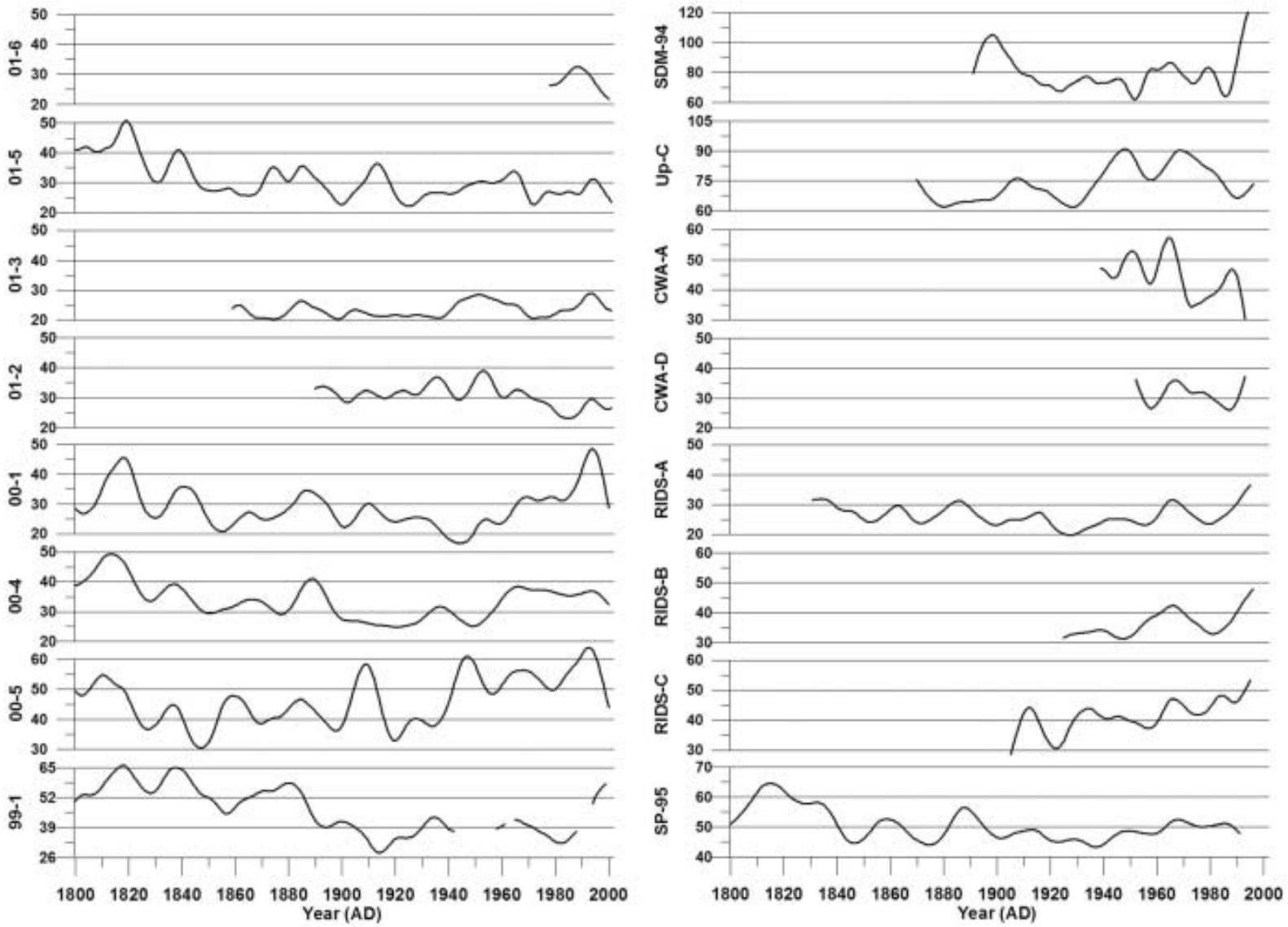

Fig. 7. Robust-spline smoothed annual excess sulfate $\left(\mathrm{rxsSO}_{4}{ }^{2-}\right)$ concentrations for each ice core for the years $1800-2002$. All concentrations are in parts per billion. Vertical lines represent 10 year increments. Note scale change from site to site.

between annual accumulation rate and $\mathrm{SO}_{4}{ }^{2-}$ are inconsistent and highly variable from site to site. The associations range from almost zero to $<50 \%$. These results suggest that although some portion of the $\mathrm{SO}_{4}{ }^{2-}$ is being deposited by wet deposition, another portion is deposited without being associated with wet precipitation. Because the dry-deposition velocity and wet-scavenging ratio for $\mathrm{SO}_{4}{ }^{2-}$ in West Antarctica are not well constrained and there is no consistent association between ion concentration and accumulation rate, flux corrections for accumulation were not applied.

\section{Sea-salt $\mathrm{SO}_{4}{ }^{2-}$}

In Figure $4 \mathrm{a}$ the mean $\mathrm{SsSO}_{4}{ }^{2-}$ concentrations for sites located above $1000 \mathrm{~m}$ elevation (Fig. 1) are seen to display a relatively consistent range of values $(\sim 4-7 \mathrm{ppb})$, apart from site 99-1 which has a mean $\mathrm{ssSO}_{4}{ }^{2-}$ concentration of $\sim 11 \mathrm{ppb}$. The high mean $\mathrm{ssSO}_{4}{ }^{2-}$ value observed at site 99-1 may be due to enhanced lower-tropospheric circulation near this site resulting in stronger advection of marine air masses to the area located over and to the east of the Ross Ice Shelf (Kreutz and Mayewski, 1999). Sites located below $1000 \mathrm{~m}$ elevation (SDM-94, Up-C and CWA-A) have mean $\mathrm{ssSO}_{4}{ }^{2-}$ concentrations of $\sim 12-30 \mathrm{ppb}$ and they are located to the west of site 99-1. The South Pole site has a very low mean $\mathrm{ssSO}_{4}{ }^{2-}$ concentration of $\sim 3 \mathrm{ppb}$.

Comparison between concentrations of $\mathrm{SsSO}_{4}{ }^{2-}$, annual accumulation and distance from the coast (Fig. 4b and c) does not immediately reveal any clear trends, but if the sites below 1000 m elevation, site 99-1 and the South Pole site, are ignored, the remaining sites display relatively similar $\mathrm{ssSO}_{4}{ }^{2-}$ concentration values $(\sim 4-7 \mathrm{ppb})$. These results suggest that two distinct depositional regimes occur over West Antarctica. One affects sites above $1000 \mathrm{~m}$ elevation, and the other affects sites below $1000 \mathrm{~m}$ elevation. This supports the previous findings of Kreutz and Mayewski (1999) that lower-tropospheric circulation is enhanced in the SDM-94 vicinity because of stronger advection of marine air masses to this area. The most likely aerosol source for the low-elevation sites to the east of the Ross Ice Shelf is the Ross Sea.

Inspection of the annual $\mathrm{ssSO}_{4}{ }^{2-}$ concentrations reveals no significant long-term trends (Fig. 5). However, sites with the highest concentrations display the greatest concentration variability. An EOF (Table 2a) performed on ten cores with annual $\mathrm{SsSO}_{4}{ }^{2-}$ values spanning the years 1891-1991 reveals a relatively strong association (EOF1, 20\% total variance and $21-46 \%$ variance of each core) of SP-95 with other sites located above $1000 \mathrm{~m}$ elevation apart from site 01-5 (Table 2a). This suggests that South Pole receives a significant fraction of its $\mathrm{SsSO}_{4}{ }^{2-}$ aerosols from the same air masses that supply West Antarctic sites located above $1000 \mathrm{~m}$ elevation. Statistical associations also occur between sites 01-5 and SDM-94: for example, in Table 2a EOF4 (10\% total variance, $32 \%$ and $44 \%$ variance of each core) these two sites are positively correlated, and in Table 2a EOF6 (9\% total variance, $40 \%$ and $23 \%$ variance of each core) they are negatively correlated. This positivenegative association may be related to findings by Bromwich and others (2004) who noted that the El Niño-Southern 
Table 2. EOF of annual sea-salt sulfate concentrations for (a) 1891-1991 and (b) 1939-91. The row immediately below the EOF number row signifies total variance $(\%)$

\begin{tabular}{|c|c|c|c|c|c|c|c|c|c|c|c|c|c|}
\hline Location & $\begin{array}{c}\text { EOF1 } \\
20\end{array}$ & $\begin{array}{c}\text { EOF2 } \\
13\end{array}$ & $\begin{array}{c}\text { EOF3 } \\
12\end{array}$ & $\begin{array}{c}\text { EOF4 } \\
10\end{array}$ & $\begin{array}{c}\text { EOF5 } \\
10\end{array}$ & $\begin{array}{c}\text { EOF6 } \\
9\end{array}$ & $\begin{array}{c}\text { EOF7 } \\
7\end{array}$ & $\begin{array}{c}\text { EOF8 } \\
7\end{array}$ & $\begin{array}{c}\text { EOF9 } \\
6\end{array}$ & $\begin{array}{c}\text { EOF10 } \\
5\end{array}$ & & & \\
\hline $01-5$ & 1 & -15 & 1 & 32 & -8 & 40 & -3 & -1 & 0 & 0 & & & \\
\hline $01-3$ & 21 & -11 & -36 & -5 & -4 & -1 & -5 & 2 & -3 & 14 & & & \\
\hline $01-2$ & 37 & 1 & -1 & 1 & 11 & 9 & 26 & 5 & -10 & 0 & & & \\
\hline $00-1$ & 46 & 4 & -4 & 0 & 0 & 0 & 4 & -16 & 25 & 1 & & & \\
\hline RIDS-A & 8 & -9 & 46 & 0 & -8 & -9 & 5 & -5 & -3 & 6 & & & \\
\hline $00-4$ & 30 & 15 & -3 & 8 & -13 & -8 & -4 & -2 & -7 & -11 & & & \\
\hline $00-5$ & 37 & -5 & 10 & -2 & -3 & 0 & -1 & 29 & 9 & -4 & & & \\
\hline SDM-94 & 0 & -10 & -1 & 44 & 20 & -23 & 0 & 1 & 1 & 0 & & & \\
\hline UP-C & 0 & 64 & 7 & 5 & 0 & 0 & -4 & 6 & 0 & 13 & & & \\
\hline SP-95 & 21 & -1 & 9 & -7 & 32 & 2 & -22 & -5 & -2 & 0 & & & \\
\hline \multicolumn{14}{|l|}{ (b) } \\
\hline Location & EOF1 & EOF2 & EOF3 & EOF4 & EOF5 & EOF6 & EOF7 & EOF8 & EOF9 & EOF10 & EOF11 & EOF12 & EOF13 \\
\hline & 19 & 12 & 10 & 9 & 8 & 8 & 7 & 6 & 6 & 4 & 4 & 3 & 2 \\
\hline $01-5$ & 2 & -16 & -7 & -11 & -2 & -27 & 9 & 4 & -18 & 0 & -2 & 0 & -1 \\
\hline 01-3 & 9 & -18 & -17 & 4 & 33 & 4 & 1 & 0 & 0 & -1 & 0 & 11 & 1 \\
\hline 01-2 & 47 & 0 & -9 & -4 & 0 & 1 & 0 & 7 & 0 & -9 & 15 & -6 & 0 \\
\hline 00-1 & 55 & 2 & 0 & 0 & 0 & 7 & -1 & -1 & -3 & 21 & 1 & 2 & -6 \\
\hline RIDS-A & 18 & -2 & 33 & -1 & -2 & -6 & 6 & -16 & 0 & 0 & 11 & 2 & 2 \\
\hline $00-4$ & 29 & -1 & -17 & 21 & -14 & -1 & 0 & -2 & 0 & 2 & -2 & -3 & 9 \\
\hline $00-5$ & 46 & 0 & 4 & 17 & 1 & -4 & 0 & -2 & 2 & -7 & -9 & 0 & -8 \\
\hline RIDS-B & -3 & -1 & 6 & 34 & -8 & 9 & 19 & 16 & -2 & 0 & 2 & 0 & 0 \\
\hline RIDS-C & 12 & -4 & 5 & -20 & -4 & 38 & 2 & -1 & -1 & -3 & -10 & 0 & 1 \\
\hline SDM-94 & -2 & -37 & -5 & -2 & -20 & 0 & 0 & 0 & 30 & 0 & 0 & 2 & -2 \\
\hline UP-C & 0 & 52 & -8 & 0 & -19 & 0 & 0 & 0 & 0 & -7 & 0 & 13 & 0 \\
\hline CWA-A & 0 & 26 & -7 & -3 & 3 & 0 & 48 & -1 & 8 & 2 & 0 & -1 & 0 \\
\hline SP-95 & 30 & 2 & 14 & -2 & 1 & -4 & -1 & 31 & 7 & 2 & -2 & 2 & 3 \\
\hline
\end{tabular}

Oscillation (ENSO) phenomenon causes a pronounced dipole structure over the Ross Ice Shelf-Marie Byrd Land area and over the Weddell Sea-Filchner/Ronne Ice Shelf. The dipole structure is observed in surface temperatures, meridional winds, cloud fraction and precipitation. An EOF of annual $\mathrm{ssSO}_{4}{ }^{2-}$ concentrations from 13 cores spanning the years 1939-91 yielded similar results (Table 2 b) between SP-95 and other sites located above $1000 \mathrm{~m}$ elevation (EOF1, 19\% total variance and $12-55 \%$ variance of each core). SDM-94 also displays similar positive-negative associations with site $01-5$ (EOF2, 12\% total variance, $37 \%$ and $16 \%$ variance of each core; EOF9, $6 \%$ total variance, $18 \%$ and $30 \%$ variance of each core). The similarity between these two EOFs implies that the $\mathrm{ssSO}_{4}{ }^{2-}$ deposition has remained relatively constant over West Antarctica for at least the last century.

\section{Excess $\mathrm{SO}_{4}{ }^{2-}$}

The $\mathrm{xsSO}_{4}{ }^{2-}$ signals for the ice-core records in this study are more complex than $\mathrm{ssSO}_{4}{ }^{2-}$ signals because the former have multiple sources. The location of a particular site with respect to physical parameters such as elevation and distance inland is critical for deciphering the $\mathrm{xsSO}_{4}{ }^{2-}$ signal. Examination of the data in Figure $4 d$ reveals that $\mathrm{xsSO}_{4}{ }^{2-}$ concentrations decrease as elevation increases to approximately $1700 \mathrm{~m}$ a.s.I. Above this elevation, the decreasing trend in $\mathrm{xsSO}_{4}{ }^{2-}$ concentration switches and, as elevation increases, $\mathrm{xsSO}_{4}{ }^{2-}$ concentrations rise, although not as sharply as they decrease from sea level. This relationship illustrates the effects of multiple $\mathrm{xsSO}_{4}{ }^{2-}$ sources, local biogenic $\mathrm{SO}_{4}{ }^{2-}$ near the coast, and mid-/upper-tropospheric/stratospheric $\mathrm{SO}_{4}{ }^{2-}$ input to higherelevation areas.

Two $\mathrm{xsSO}_{4}{ }^{2-}$ EOFs (Table $3 \mathrm{a}$ and b) demonstrate the separation between sites located above and below $1000 \mathrm{~m}$ elevation (both EOF1, 29\% total variance and 16-69\% variance of each core located above $1000 \mathrm{~m}, 0-5 \%$ for cores located below $1000 \mathrm{~m}$ ), suggestive of two separate source regions or transport pathways supplying $\mathrm{xsSO}_{4}{ }^{2-}$ to West Antarctica. All the core sites located above $1000 \mathrm{~m}$ elevation exhibit a decrease in $\mathrm{xsSO}_{4}{ }^{2-}$ concentrations as accumulation increases (Fig. 4e). However, this only occurs up to a threshold annual accumulation value of 20$24 \mathrm{~cm}$ w.e. Sites with annual accumulation values greater than this threshold do not display any significant trends in $\mathrm{xSSO}_{4}{ }^{2-}$ concentration. Sites located below $1000 \mathrm{~m}$ elevation (SDM-94, Up-C and CWA-A) do not show any clear trends associated with annual accumulation, although these sites do exhibit a decreasing trend in $\mathrm{xsSO}_{4}{ }^{2-}$ concentrations vs distance from the nearest open water (Fig. 4f). Sites located above $1000 \mathrm{~m}$ elevation display the opposite trend: increasing $\mathrm{xsSO}_{4}{ }^{2-}$ concentrations vs distance from the nearest open water (Fig. 4f). These results suggest that sites located above $1000 \mathrm{~m}$ elevation receive the majority of their $\mathrm{xsSO}_{4}{ }^{2-}$ from mid-/uppertropospheric/stratospheric air masses and that sites located 
Table 3. EOF of annual excess sulfate concentrations for (a) 1891-1991 and (b) 1939-91. The row immediately below the EOF number row signifies total variance $(\%)$

\begin{tabular}{|c|c|c|c|c|c|c|c|c|c|c|}
\hline Location & $\begin{array}{c}\text { EOF1 } \\
29\end{array}$ & $\begin{array}{c}\text { EOF2 } \\
13\end{array}$ & $\begin{array}{c}\text { EOF3 } \\
11\end{array}$ & $\begin{array}{c}\text { EOF4 } \\
10\end{array}$ & $\begin{array}{c}\text { EOF5 } \\
8\end{array}$ & $\begin{array}{c}\text { EOF6 } \\
8\end{array}$ & $\begin{array}{c}\text { EOF7 } \\
7\end{array}$ & $\begin{array}{c}\text { EOF8 } \\
5\end{array}$ & $\begin{array}{c}\text { EOF9 } \\
5\end{array}$ & $\begin{array}{c}\text { EOF10 } \\
4\end{array}$ \\
\hline $01-5$ & 38 & -2 & -1 & -10 & 0 & 28 & 11 & -2 & 0 & -7 \\
\hline $01-3$ & 52 & -10 & 0 & 0 & 1 & 1 & -2 & 23 & -11 & 0 \\
\hline $01-2$ & 10 & -23 & 16 & -16 & -5 & -27 & 0 & -2 & 0 & -1 \\
\hline $00-1$ & 18 & 47 & -6 & 0 & -7 & -5 & -3 & 0 & -4 & -9 \\
\hline RIDS-A & 35 & 0 & 2 & 15 & 31 & -1 & -2 & 0 & 5 & -7 \\
\hline $00-4$ & 37 & 10 & 0 & 3 & 0 & -6 & 36 & 3 & 1 & 3 \\
\hline $00-5$ & 47 & -1 & -9 & 0 & -12 & 0 & -10 & 1 & 18 & 2 \\
\hline SDM-94 & 0 & 5 & 62 & 11 & -14 & 6 & 0 & 1 & 1 & -1 \\
\hline UP-C & 0 & -26 & -10 & 47 & -11 & 0 & 1 & -3 & -2 & 0 \\
\hline SP-95 & 57 & 2 & 4 & 0 & 1 & 1 & -2 & -16 & -5 & 12 \\
\hline
\end{tabular}

\begin{tabular}{|c|c|c|c|c|c|c|c|c|c|c|c|c|c|}
\hline Location & $\begin{array}{c}\text { EOF1 } \\
29\end{array}$ & $\begin{array}{c}\text { EOF2 } \\
12\end{array}$ & $\begin{array}{c}\text { EOF3 } \\
10\end{array}$ & $\begin{array}{c}\text { EOF4 } \\
8\end{array}$ & $\begin{array}{c}\text { EOF5 } \\
8\end{array}$ & $\begin{array}{c}\text { EOF6 } \\
7\end{array}$ & $\begin{array}{c}\text { EOF7 } \\
5\end{array}$ & $\begin{array}{c}\text { EOF8 } \\
5\end{array}$ & $\begin{array}{c}\text { EOF9 } \\
5\end{array}$ & $\begin{array}{c}\text { EOF10 } \\
3\end{array}$ & $\begin{array}{c}\text { EOF11 } \\
3\end{array}$ & $\begin{array}{c}\text { EOF12 } \\
2\end{array}$ & $\begin{array}{c}\text { EOF13 } \\
2\end{array}$ \\
\hline $01-5$ & 38 & -3 & -6 & -3 & 0 & 30 & -2 & 1 & -9 & -2 & 1 & 0 & -5 \\
\hline $01-3$ & 50 & -25 & -2 & -1 & 0 & 0 & 0 & 1 & -4 & 6 & 0 & -3 & 9 \\
\hline $01-2$ & 21 & -26 & 5 & -17 & -1 & -3 & 0 & -1 & 13 & -11 & 1 & -1 & 0 \\
\hline 00-1 & 16 & 44 & 0 & 0 & 1 & -17 & -9 & -1 & -3 & -1 & 1 & -6 & 0 \\
\hline RIDS-A & 36 & -1 & 0 & 15 & -1 & -4 & 37 & 0 & -1 & 0 & 0 & -1 & -2 \\
\hline $00-4$ & 42 & 12 & 3 & -3 & 8 & 3 & 5 & -6 & -2 & -4 & -7 & 2 & 3 \\
\hline $00-5$ & 37 & -2 & -18 & 2 & 5 & -8 & -2 & 8 & 2 & 0 & -12 & 1 & -2 \\
\hline RIDS-B & 44 & 0 & 17 & -1 & -1 & 1 & -2 & -11 & 3 & 16 & -1 & 0 & -3 \\
\hline RIDS-C & 21 & 15 & -9 & 15 & -2 & 15 & 0 & 0 & 19 & 0 & 0 & -1 & 1 \\
\hline SDM-94 & 2 & 3 & 51 & 0 & 15 & 1 & 1 & 27 & 1 & 0 & 0 & -1 & 0 \\
\hline UP-C & -2 & -13 & 0 & 17 & 55 & 0 & -1 & -9 & 0 & 0 & 2 & 0 & 0 \\
\hline CWA-A & 5 & -5 & 24 & 34 & -12 & 0 & -12 & 0 & -3 & -4 & -1 & 1 & 0 \\
\hline
\end{tabular}

below $1000 \mathrm{~m}$ elevation do not receive a significant fraction of their $\mathrm{xsSO}_{4}{ }^{2-}$ from this source. Previous work suggests that the $\mathrm{xsSO}_{4}{ }^{2-}$ supplied to sites located below $1000 \mathrm{~m}$ is deposited from lower-tropospheric air masses (Kreutz and Mayewski, 1999).

\section{Remaining excess $\mathrm{SO}_{4}{ }^{2-}$}

Examination of the rxsSO ${ }_{4}{ }^{2-}$ curves in Figure 7 reveals that an overall decreasing trend takes place in all records from 1800 to $\sim 1940$. Several of the $\mathrm{rxSSO}_{4}{ }^{2-}$ records exhibit an increasing trend from $\sim 1940$ to $\sim 1990$ (00-1, 00-4, 00-5, RIDS-A, RIDS-B, RIDS-C and, to a lesser extent, SP-95). Several sites exhibit a decrease in $\mathrm{rxsSO}_{4}{ }^{2-}$ during this same time period (01-5, 01-3 and 01-2). The remaining records do not show any significant trends or are too short to make an informed determination (site 99-1 is ignored beyond $\sim 1940$ because of missing data). The opposing $\mathrm{rxSSO}_{4}{ }^{2-}$ trends observed in our records suggest that the source is not anthropogenic. If an anthropogenic rise in $\mathrm{rxsSO}_{4}{ }^{2-}$ were occurring, it should occur in all $\mathrm{rxsSO}_{4}{ }^{2-}$ records simultaneously. A second argument against an anthropogenically forced rise in $\mathrm{rxSSO}_{4}{ }^{2-}$ is the fact that the rise which does occur from 1939 to 1991 does not increase $\mathrm{rxsSO}_{4}{ }^{2-}$ levels higher than they were during the early 19 th century.

EOF results of $\mathrm{rxsSO}_{4}{ }^{2-}$ for the years 1891-1991 (Table $4 \mathrm{a}$ ) reveal a strong association (EOF1, 40\% total variance and $13-77 \%$ variance of each core) between cores
01-5, 01-3, 00-1, RIDS-A, 00-4, 00-5, Up-C and SP-95. This 1891-1991 EOF captures the significant structure in the $\mathrm{rxsSO}_{4}{ }^{2-}$ curves. The majority of this structure consists of broad $\mathrm{rxSSO}_{4}{ }^{2-}$ peaks centered around $\sim 1910, \sim 1947$ and 1965 (Fig. 7). The large $1965 \mathrm{rxsSO}_{4}{ }^{2-}$ peak indicates that some fraction of volcanic $\mathrm{SO}_{4}{ }^{2-}$ is still present in these records after the robust-spline residuals are removed. However, the $\sim 1910$ and $\sim 1947 \mathrm{rxsSO}_{4}{ }^{2-}$ peaks may be a result of local volcanic eruptions or increases from nonvolcanic sources such as marine biogenic $\mathrm{SO}_{4}{ }^{2-}$.

The EOF results of rxsSO$_{4}{ }^{2-}$ for the years 1939-91 reveal a strong negative association (EOF1, 41\% total variance and $13-84 \%$ variance of each core) between two groups of cores (Table 4b). The first group consists of 01-5, 01-3 and 01-2. The second group consists of 00-1, 00-4, RIDS-A, RIDS-B, RIDS-C, SDM-94 and SP-95. This 1939-91 EOF captures the overall long-term trend in $\mathrm{rxsSO}_{4}{ }^{2-}$ that takes place during this time period. The reason for the negative association is that the first group of cores $(01-5,01-3$ and 01-2) display a decreasing trend in $\mathrm{rxsSO}_{4}{ }^{2-}$ concentrations from 1939 to 1991 and the second group (00-1, 00-4, RIDS-A, RIDS-B, RIDS-C, SDM-94 and SP-95) displays an increasing trend (Fig. 7). The trends in these rxsSO$_{4}{ }^{2-}$ records suggest that a climate transition takes place over West Antarctica during 1940 . At this time the atmospheric circulation over West Antarctica changes in such a way as to increase the transport of $\mathrm{rxsSO}_{4}{ }^{2-}$ to central West Antarctica. 
Table 4. EOF of robust-spline smoothed annual excess sulfate concentrations for (a) 1891-1991 and (b) 1939-91. The row immediately below the EOF number row signifies total variance $(\%)$

\begin{tabular}{|c|c|c|c|c|c|c|c|c|c|c|}
\hline \\
\hline \multirow[t]{2}{*}{ Location } & EOF1 & EOF2 & EOF3 & EOF4 & EOF5 & EOF6 & EOF7 & EOF8 & EOF9 & EOF10 \\
\hline & 40 & 24 & 13 & 7 & 6 & 5 & 3 & 2 & 1 & 1 \\
\hline $01-5$ & 23 & 27 & 32 & -9 & -3 & -2 & 0 & -1 & -3 & 0 \\
\hline 01-3 & 13 & 54 & 0 & -3 & 12 & 16 & 0 & -1 & 0 & -1 \\
\hline 01-2 & -25 & 38 & 11 & 2 & -9 & 7 & 0 & 7 & 0 & 0 \\
\hline 00-1 & 41 & -40 & 0 & -9 & 0 & 2 & 0 & 6 & 0 & -1 \\
\hline RIDS-A & 75 & 0 & 4 & 0 & -1 & -1 & 18 & 0 & 2 & 0 \\
\hline $00-4$ & 52 & -15 & 0 & 14 & -1 & 14 & 0 & -1 & -2 & 1 \\
\hline $00-5$ & 60 & 14 & -9 & 0 & 8 & -2 & 0 & 5 & 0 & 2 \\
\hline SDM-94 & 2 & -12 & 62 & 9 & 14 & -1 & -1 & 0 & 0 & 0 \\
\hline UP-C & 31 & 34 & -7 & 19 & -1 & -5 & -1 & 0 & 0 & -2 \\
\hline SP-95 & 77 & -2 & 1 & 0 & -5 & 0 & -10 & -1 & 3 & 0 \\
\hline \multirow[t]{2}{*}{ Location } & EOF1 & EOF2 & EOF3 & EOF4 & EOF5 & EOF6 & EOF7 & EOF8 & EOF9 & EOF10 \\
\hline & 41 & 23 & 12 & 11 & 6 & 4 & 2 & 1 & 0 & 0 \\
\hline $01-5$ & -13 & 65 & -5 & 4 & -10 & -1 & 2 & -1 & 0 & 0 \\
\hline $01-3$ & -42 & 26 & 0 & -25 & -1 & -3 & 1 & 0 & 0 & 0 \\
\hline 01-2 & -68 & 17 & -1 & 8 & 0 & 0 & -3 & 2 & 0 & 0 \\
\hline $00-1$ & 80 & 0 & -1 & -3 & -6 & -3 & -1 & 6 & 0 & 0 \\
\hline RIDS-A & 44 & 42 & 3 & 0 & 5 & 1 & -5 & 0 & 0 & 0 \\
\hline $00-4$ & 84 & 0 & -7 & 6 & 0 & 1 & 0 & -1 & -1 & 0 \\
\hline $00-5$ & 8 & 17 & 51 & -8 & 3 & -12 & -1 & -1 & 0 & 0 \\
\hline RIDS-B & 28 & 50 & -16 & 0 & -2 & 0 & -3 & 0 & 0 & 0 \\
\hline RIDS-C & 76 & 0 & 10 & -2 & 1 & 7 & 2 & 0 & 2 & 0 \\
\hline SDM-94 & 20 & 14 & -24 & 3 & 26 & -7 & 5 & 1 & 0 & 0 \\
\hline UP-C & -8 & 1 & 24 & 66 & 1 & 0 & 0 & 0 & 0 & 0 \\
\hline CWA-A & -9 & 62 & 4 & -2 & 0 & 20 & 2 & 1 & -1 & 0 \\
\hline
\end{tabular}

\section{Volcanic $\mathrm{SO}_{4}{ }^{2-}$ peaks}

There are many volcanic events evident in the 16 ice-core $\mathrm{xsSO}_{4}{ }^{2-}$ records used in this study (Fig. 6). The strength of the volcanic signal preserved in polar ice varies according to the location of the core and the size, sulfur content, explosivity and location of the eruption. Global-scale volcanic eruptions, such as Pinatubo 1991, erupt with sufficient explosive force to inject large amounts of volcanic material directly into the stratosphere. Significant amounts of $\mathrm{H}_{2} \mathrm{~S}$ and $\mathrm{SO}_{2}$ gas are emitted during a global-scale eruption. The $\mathrm{H}_{2} \mathrm{~S}$ is quickly converted to $\mathrm{SO}_{2}$, and this volcanic $\mathrm{SO}_{2}$ is subsequently oxidized to $\mathrm{H}_{2} \mathrm{SO}_{4}$ (Junge and others, 1961; Berresheim and others, 1995). Elevated stratospheric $\mathrm{SO}_{4}{ }^{2-}$ concentrations can take as long as 3-4 years to return to pre-volcanic levels following a globalscale eruption (Self and others, 1981). As a result, volcanic $\mathrm{SO}_{4}{ }^{2-}$ in the stratosphere can spread over the entire globe before it is removed by mechanisms such as sedimentation.

In this study, global-scale eruptions (e.g. Tambora 1815, Krakatau 1883 and Agung 1963) appear simultaneously as $2 \sigma$ peaks in all of the robust-spline residual $\mathrm{xsSO}_{4}{ }^{2-}$ records from sites located above $1000 \mathrm{~m}$ elevation, but they are not obvious at sites located below $1000 \mathrm{~m}$ elevation, such as SDM-94, Up-C and CWA-A (Fig. 6). The lack of global-scale volcanic eruption signatures in low-elevation records supports the idea that coastal and low-elevation sites in Antarctica are not strongly influenced by mid-/upper-tropospheric/stratospheric air masses.

\section{CONCLUSIONS}

The 16 high-resolution sub-annual records presented in this study preserve every year of chemical deposition in detail for the full length of each record. The dating accuracy of these records is estimated to be better than 1 year. Each record is calibrated using several known global-scale volcanic horizons. The detailed preservation of annual layers in the ice cores provides a remarkable opportunity for the investigation of major contributions to the Antarctic $\mathrm{SO}_{4}{ }^{2-}$ budget, notably: $\mathrm{ssSO}_{4}{ }^{2-}$, volcanic-event $\mathrm{xsSO}_{4}{ }^{2-}$ and $\mathrm{rxsSO}_{4}{ }^{2-}$.

These data show that sites located below $1000 \mathrm{~m}$ elevation (SDM-94, Up-C and CWA-A) receive higher concentrations of $\mathrm{ssSO}_{4}{ }^{2-}$ than sites located above $1000 \mathrm{~m}$ elevation. EOF results suggest that the sites located above $1000 \mathrm{~m}$ elevation receive a large percentage of $\mathrm{ssSO}_{4}{ }^{2-}$ from common air masses/sources, and sites located below $1000 \mathrm{~m}$ elevation receive $\mathrm{ssSO}_{4}{ }^{2-}$ from common air masses/sources that are separate from the air masses/sources supplying sites located above $1000 \mathrm{~m}$ elevation.

Concentration trends imply a dual source for West Antarctic $\mathrm{xsSO}_{4}{ }^{2-}$ : lower-tropospheric near the coast and mid-/upper-tropospheric/stratospheric for higher-elevation areas. These results highlight the relative importance of different $\mathrm{xsSO}_{4}{ }^{2-}$ sources and pathways for sites at different elevations. The $\mathrm{rxsSO}_{4}{ }^{2-}$ records reveal an overall concentration decrease at all sites over the period 1800 to $\sim 1940$. Several of the $\mathrm{rxSSO}_{4}{ }^{2-}$ records also exhibit an increasing trend from $\sim 1940$ to $\sim 1990$, and several exhibit a decrease 
during this same time period. These $\mathrm{rxsSO}_{4}{ }^{2-}$ trends suggest that a significant shift in the spatial distribution of $\mathrm{SO}_{4}{ }^{2-}$ took place over West Antarctica at $\sim 1940$. The atmospheric circulation changed in such a way as to increase the transport of $\mathrm{rxSSO}_{4}{ }^{2-}$ to inland West Antarctica and decrease it to other West Antarctic sites. This implies a major change in atmospheric circulation at this time which could not have been inferred from a single ice core, highlighting the importance and value of having an array of accurately dated spatially distributed records. Our records do not imply an anthropogenic source for any of the observed trends in $\mathrm{rxSSO}_{4}{ }^{2-}$.

In our records all global-scale volcanic eruptions appear as $2 \sigma$ peaks, as determined using residuals from a robust spline of the $\mathrm{xsSO}_{4}{ }^{2-}$ records. Global-scale volcanic eruptions cannot be consistently resolved in the $\mathrm{xSSO}_{4}{ }^{2-}$ records for sites located below $1000 \mathrm{~m}$ elevation because the majority of volcanic $\mathrm{SO}_{4}{ }^{2-}$ from global-scale eruptions is transported to Antarctica through the mid-/upper-troposphere/stratosphere, and sites located below $1000 \mathrm{~m}$ elevation do not receive a significant fraction of $\mathrm{xSSO}_{4}{ }^{2-}$ from this source. High $\mathrm{SsSO}_{4}{ }^{2-}$ and local marine biogenic $\mathrm{SO}_{4}{ }^{2-}$ further obscure much of the volcanic $\mathrm{SO}_{4}{ }^{2-}$ present at these lower-elevation sites. The $\mathrm{xsSO}_{4}{ }^{2-}$ signals from global-scale volcanic eruptions can be used as reliable depth-age markers in West Antarctic cores located above $1000 \mathrm{~m}$ elevation, but cannot be used definitively at sites located below $1000 \mathrm{~m}$ elevation.

\section{REFERENCES}

Bates, T. S., B. K. Lamb, A. Guenther, J. Dignon and R. E. Stoiber. 1992. Sulfur emissions to the atmosphere from natural sources. J. Atmos. Chem., 14(1-4), 315-337.

Battle, M. and 10 others. 1996. Atmospheric gas concentrations over the past century measured in air from firm at the South Pole. Nature, 383(6597), 231-235.

Bergin, M. H., C. I. Davidson, J. E. Dibb, J.-L. Jaffrezo, H. D. Kuhns and S. N. Pandis. 1995. A simple model to estimate atmospheric concentrations of aerosol chemical species based on snow core chemistry at Summit, Greenland. Geophys. Res. Lett., 22(24), 3517-3520.

Bergin, M., E. A. Meyerson, J. E. Dibb and P. A. Mayewski. 1998. Relationship between continuous aerosol measurements and firn core chemistry over a 10 year period at the South Pole. Geophys. Res. Lett., 25(8), 1189-1192.

Berresheim, H., P. H. Wine and D. D. Davis. 1995. Sulfur in the atmosphere. In Singh, H.B., ed. Composition, chemistry and climate of the atmosphere. New York, Van Nostrand Reinhold, 251-307.

Bindschadler, R. A. 1998. Future of the West Antarctic ice sheet. Science, 282(5388), 428-429.

Bromwich, D. H., A. J. Monaghan and Z. Guo. 2004. Modeling the ENSO modulation of Antarctic climate in the late 1990s with Polar MM5. J. Climate, 17(3), 109-132.

Charlson, R. J., J. Langner and H. Rohde. 1990. Sulfate aerosol and climate. Nature, 348(6296), 22.

Cullather, R.I., D. H. Bromwich and M. L. Van Woert. 1996. Interannual variations in Antarctic precipitation related to El-Niño-Southern Oscillation. J. Geophys. Res., 101(D14), 19,109-19,118.

Delmas, R. J. 1982. Antarctic sulphate budget. Nature, 299(5885), $677-678$.

Delmas, R. and C. Boutron. 1978. Sulfate in Antarctic snow: spatiotemporal distribution. Atmos. Environ., 12(1-3), 723-728.

Dibb, J. E. and S. I. Whitlow. 1996. Recent climatic anomalies and their impact on snow chemistry at South Pole, 1987-1994. Geophys. Res. Lett., 23(10), 1115-1118.

Harder, S., S. G. Warren and R. J. Charlson. 2000. Sulphate in air and snow at the South Pole: implications for transport and deposition at sites with low snow accumulation. J. Geophys. Res., 105(D18), 22,825-22,832.

Hogan, A. 1997. A synthesis of warm air advection to the South Polar Plateau. J. Geophys. Res., 102(D12), 14,009-14,020.

Hogan, A., S. Barnard, J. Samson and W. Winters. 1982. The transport of heat, water vapor and particulate material to the South Polar Plateau. J. Geophys. Res., 87(C6), 4287-4292.

Holland, H. D. 1978. The chemistry of the atmosphere and oceans. New York, Wiley-Interscience.

Isaksson, E., W. Karlén, P. Mayewski, M. Twickler and S. Whitlow. 2001. A high-altitude snow chemistry record from Amundsenisen, Dronning Maud Land, Antarctica. J. Glaciol., 47(158), 489-496.

Junge, C.E., C.W. Chagnon and J.E. Manson. 1961. Stratospheric aerosols. J. Meteorol., 18(1), 81-108.

Kreutz, K.J. and P.A. Mayewski. 1999. Spatial variability of Antarctic surface snow glaciochemistry: implications for paleoatmospheric circulation reconstructions. Antarct. Sci., 11(1), 105-118.

Kreutz, K. J., P. A. Mayewski, M. S. Twickler and S. I. Whitlow. 1996. Ice-core geochemical reconnaissance in inland West Antarctica. Antarct. J. US, 31(2), Review 1996, 51-52.

Kreutz, K.J. and 11 others. 1999. Seasonal variations of glaciochemical, isotopic and stratigraphic properties in Siple Dome (Antarctica) surface snow. Ann. Glaciol., 29, 38-44.

Kreutz, K.J., P.A. Mayewski, L.D. Meeker, M.S. Twickler and S. I. Whitlow. 2000. The effect of spatial and temporal accumulation rate variability in West Antarctica on soluble ion deposition. Geophys. Res. Lett., 27(16), 2517-2520.

Legrand, M. 1997. Ice-core records of atmospheric sulfur. Philos. Trans. R. Soc. London, Ser. B, 352(1350), 241-250.

Legrand, M.R. and R.J. Delmas. 1987. A 220-year continuous record of volcanic $\mathrm{H}_{2} \mathrm{SO}_{4}$ in the Antarctic ice sheet. Nature, 327(6124), 671-676.

Legrand, M. and P. Mayewski. 1997. Glaciochemistry of polar ice cores: a review. Rev. Geophys., 35(3), 219-243.

Legrand, M. and E. C. Pasteur. 1998. Methane sulfonic acid to nonsea-salt sulfate ratio in coastal Antarctic aerosol and surface snow. J. Geophys. Res., 103(D9), 10,991-11,006.

Legrand, M. and D. Wagenbach. 1999. Impact of the Cerro Hudson and Pinatubo volcanic eruptions on the Antarctic air and snow chemistry. J. Geophys. Res., 104(D1), 1581-1596.

Legrand, M., C. Feniet-Saigne, E.S. Saltzman and C. Germain. 1992. Spatial and temporal variations of methanesulfonic acid and non sea salt sulfate in Antarctic ice. J. Atmos. Chem., 14(1-4), 245-260.

Liu, H., K. C. Jezek, B. Li and Z. Zhao. 2001. RADARSAT Antarctic Mapping Project digital elevation model. Version 2. Boulder, CO, National Snow and Ice Data Center.

Mayewski, P. A. and 8 others. 1993. Greenland ice core "signal" characteristics: an expanded view of climate change. J. Geophys. Res., 98(D7), 12,839-12,847.

Mayewski, P. A., M. S. Twickler and S. I. Whitlow. 1995. The Siple Dome ice core - reconnaissance glaciochemistry. Antarct. J. US, 30(5), Review 1995, 85-87.

Meyerson, E.A., P.A. Mayewski, K.J. Kreutz, L.D. Meeker, S. I. Whitlow and M.S. Twickler. 2002. The polar expression of ENSO and sea-ice variability as recorded in a South Pole ice core. Ann. Glaciol., 35, 430-436.

Minikin, A. and 7 others. 1998. Sulfur-containing species (sulfate and methanesulfonate) in coastal Antarctic aerosol and precipitation. J. Geophys. Res., 103(D9), 10,975-10,990.

Mulvaney, R. and E. W. Wolff. 1994. Spatial variability of the major chemistry of the Antarctic ice sheet. Ann. Glaciol., 20, 440-447.

O'Brien, S. R., P.A. Mayewski, L. D. Meeker, D. A. Meese, M. S. Twickler and S. I. Whitlow. 1995. Complexity of Holocene 
climate as reconstructed from a Greenland ice core. Science, 270(5244), 1962-1964.

Proposito, M. and 9 others. 2002. Chemical and isotopic snow variability along the 1998 ITASE traverse from Terra Nova Bay to Dome C, East Antarctica. Ann. Glaciol., 35, 187-194.

Prospero, J. M., D. L. Savoie, E. S. Saltzman and R. Larson. 1991. Impact of oceanic sources of biogenic sulphur on sulphate aerosol concentrations at Mawson, Antarctica. Nature, 350(6315), 221-223.

Rankin, A.M., E.W. Wol and S. Martin. 2002. Frost flowers: implications for tropospheric chemistry and ice core interpretation. J. Geophys. Res., 107(D23), 4683. (10.1029/ 2002JD002492.)

Reusch, D. B., P. A. Mayewski, S.I. Whitlow, I. I. Pittalwala and M.S. Twickler. 1999. Spatial variability of climate and past atmospheric circulation patterns from central West Antarctic glaciochemistry. J. Geophys. Res., 104(D6), 5985-6001.

Saxena, V.K., J. Anderson and N.H. Lin. 1995. Changes in Antarctic stratospheric aerosol characteristics due to volcanic eruptions as monitored by the Stratospheric Aerosol and Gas
Experiment II satellite. J. Geophys. Res., 100(D8), 16,73516,751 .

Self, S., M. Rampino and J. J. Barbera. 1981. The possible effects of large 19th and 20th century volcanic eruptions on zonal and hemispheric surface temperatures. J. Volcanol. Geotherm. Res., 11(1), 41-60.

Shaw, G. E. 1982. On the residence time of the Antarctic ice sheet sulfate aerosol. J. Geophys. Res., 87(C6), 4309-4313.

Wagenbach, D. 1996. Coastal Antarctica: atmospheric chemical composition and atmospheric transport. In Wolff, E. W. and R. C. Bales, eds. Chemical exchange between the atmosphere and polar snow. Berlin, etc., Springer-Verlag, 173-199. (NATO ASI Series I: Global Environmental Change 43.)

Whitlow, S., P. A. Mayewski and J. E. Dibb. 1992. A comparison of major chemical species seasonal concentration and accumulation at the South Pole and Summit, Greenland. Atmos. Environ., 26A(11), 2045-2054.

Zielinski, G. A. and 8 others. 1994. Record of volcanism since 7000 B.C. from the GISP2 Greenland ice core and implications for the volcano-climate system. Science, 264(5161), 948-952. 